\title{
Structural Control of Auriferous Mineralization in the Birimian: Case of the Agbahou Deposit in the Region of Divo, Côte d'Ivoire
}

\author{
N'Guessan Nestor Houssou, Marc Ephrem Allialy, Fossou Jean-Luc Hervé Kouadio, \\ Allou Gnanzou
}

Geology of Basement and Metallogeny Laboratory (GBML), Training and Research Unit of Earth Sciences and Mining Resources, University of Felix HOUPHOUET-BOIGNY, Abidjan-Cocody, Cote d'Ivoire

Email: nestor.houssou@gmail.com

How to cite this paper: Houssou, N.N., Allialy, M.E., Kouadio, F.J.-L.H. and Gnanzou, A. (2017) Structural Control of Auriferous Mineralization in the Birimian: Case of the Agbahou Deposit in the Region of Divo, Côte d'Ivoire. International Journal of Geosciences, 8, 189-204.

https://doi.org/10.4236/ijg.2017.82008

Received: December 16, 2016

Accepted: February 18, 2017

Published: February 21, 2017

Copyright $\odot 2017$ by authors and Scientific Research Publishing Inc. This work is licensed under the Creative Commons Attribution International License (CC BY 4.0).

http://creativecommons.org/licenses/by/4.0/

(c) $\underset{\mathrm{EY}}{\text { (i) Open Access }}$

\begin{abstract}
Located in the southwestern of the Oume-Fettekro greenstone belt, the Agbahou gold deposit is controlled by structural factors. Geophysics, teledetection and core data suggest the presence of NE and NW faults. However, the NEfaults define two major shear zones (ATZ: Agbahou Tectonic Zone and WTZ: West Tectonic Zone) that control the Agbahou gold mineralization. These first order structures are subparallel to the regional tectonic grain mostly north-east oriented. They seem to respectively develop on the both arms (eastern and western) of an anticline moderately plunging $\sim 25^{\circ}$ towards northeast. Each shear-zone contains several second-order shear-zones or lenses of variable direction and of $50^{\circ}-80^{\circ}$ dip. NW-faults however correspond to strike-slip faults and their development should be related to transcurrent tectonics. They acted as control channels on the distribution of gold mineralizations. The ductile-brittle character of shear-zones favored the ascent of hydrothermal fluids and the formation of multiple auriferous quartz veins: veins Type IIa and veins Type IIb relating respectively to the shear-veins and extensional veins. However, Agbahou also shows the existence of a disseminated sulphides-bearing mineralization within host-rocks. At Agbahou, the precipitation of gold probably occurred in a post to late ductile-brittle deformation period.
\end{abstract}

\section{Keywords}

Gold-Bearing Mineralization, Structural Control, Birimian, Agbahou, Ivory Coast

\section{Introduction}

The shear zones associated with birimian greenstone belts in West Africa (Hein 
et al., 2004 [1], Hein, 2010 [2], Feybesse et al., 2006 [3], Tshibubudze et al., 2009 [4], Lompo, 2010 [5]; Baratoux et al., 2011 [6], Perrouty et al., 2012 [7], etc.) have become the major structural elements that receive special attention in the search for gold mineralization. Most gold mining sites, as well as gold deposits and deposits in exploration or exploitation, seem to be aligned with these megastructures. In Côte d'Ivoire, the shear zones show an NE to ENE orientation and develop either inside the greenstone belts or in the contacts of these with the plutonites.

The Agbahou gold deposit is characterized by NE and NW lineaments, highlighted by geophysical data and remote sensing (Gillick, 2001 [8], Houssou, 2013 [9]). These lineaments have never been studied directly because of the scarcity of rock outcrops and the lack of depth work (drillholes). Recent exploration works done by BHP Minerals, Jandera (GoldIvoire), Etruscan Resources and then Endeavor Mining, including pits, trenches and drillholes, provided further details on the lithostructural context of this gold mineralization. The bidirectionality of lineaments is probably at the origin of a polyphase deformation that has generated several generations of quartz veins. Tshibubudze and Hein (2013) [10] have demonstrated such quartz veins intimately associated with the junction of NE and NW lineaments in the Essakane gold deposit in Burkina Faso. Their work made it possible to classify these quartz veins and then establish a relationship between them and gold mineralization.

Around Agbahou, several gold mineralizations are under exploration or exploitation (Bonikro, Akissi-So, Assondji-So, Agbalé, M’bazo, etc.). This region seems to be potentially rich in gold mineralizations. However, the almost total absence of outcrops and the lack of the depth work in the region have not led to make a real lithostructural study. Our work, mainly based on core drilling, is therefore a contribution to the improvement of the geological knowledge on the birimian belts and the associated gold mineralizations. The major contributions includes: 1) the precision of the nature of birimian greenstone belts in an area of deep superficial coverage; 2) the highlighting of structural factors controlling mineralizations of Agbahou.

In our study, we will present the results of our field investigations into the lithostructural control of gold mineralization in the Agbahou deposit. Particular emphasis will be placed on the types of deformation, geometric features controlling gold mineralization and their implication for mineral exploration in West Africa.

\section{Geological Context}

The Agbahou gold deposit is located at about $230 \mathrm{~km}$ at the NW of Abidjan (Côte d'Ivoire), in other words, $20 \mathrm{~km}$ by bird flight from the Bonikro gold deposit (Figure 1). The region of Agbahou belongs to the Proterozoic domain of Cote d'Ivoire, separated from the Archean domain by the fault of Sassandra (Bessoles, 1977 [11]). According to Pothin et al. (2000) [12], this Precambrian basement was structured between 3450 and $1026 \mathrm{Ma}$. Indeed, the Archean domain 


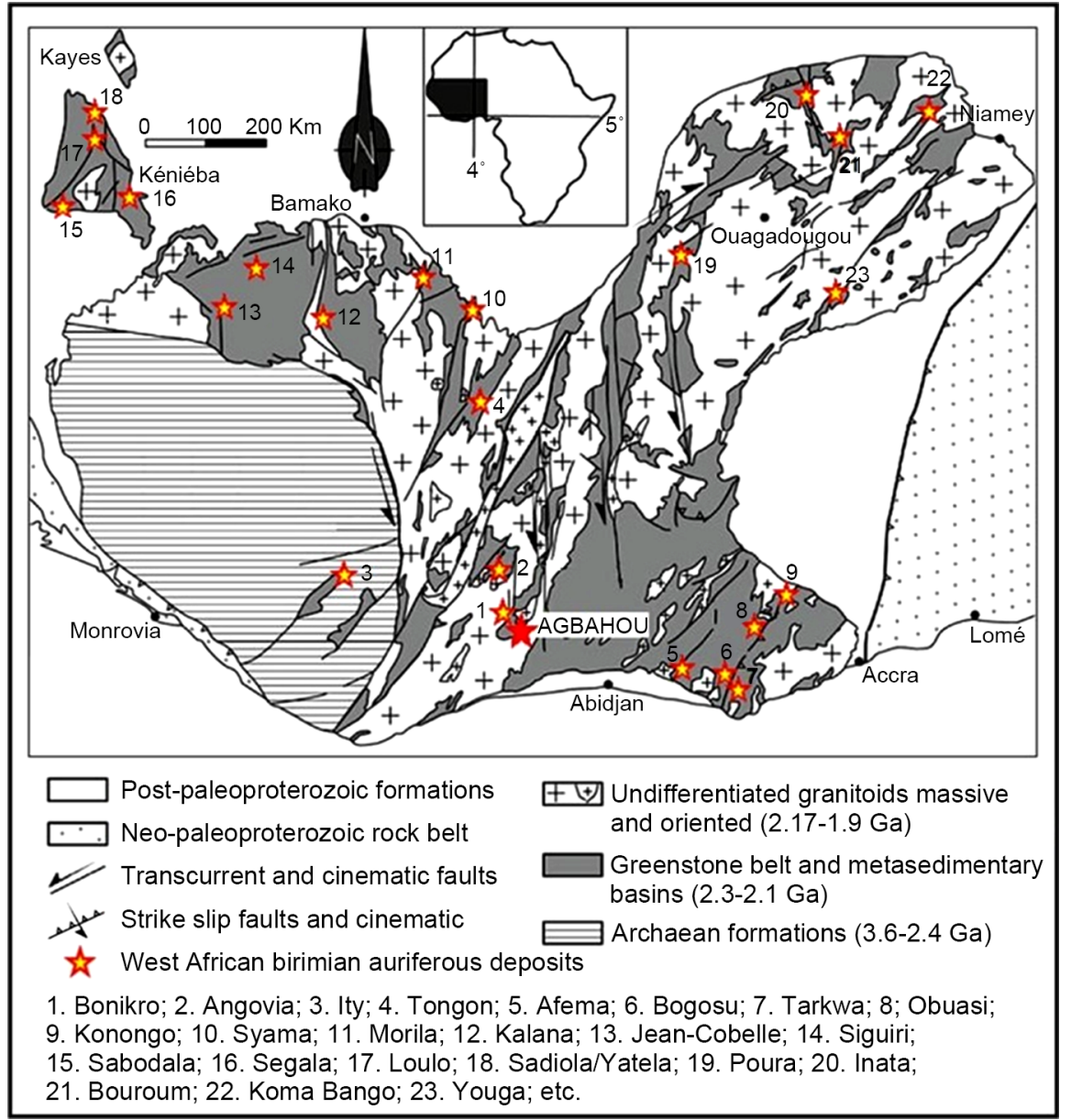

Figure 1. Simplified geological map of the West African craton with some mines and gold deposits, and the location of the Agbahou deposit (Map redesigned from Milesi et al., 1992 [13]).

or Kenema-Man domain was structured by the Leonian (3500 - $2900 \mathrm{Ma})$ and Liberian (2900 - $2500 \mathrm{Ma}$ ) orogenies. The structuring of the Proterozoic domain or Baoulé-Mossi domain on the other hand is still a subject for discussion. For some authors (Tagini, 1971 [14], Yace, 1993 [15]), the structuring took place during a single orogeny, the Eburnean (2500 - $1600 \mathrm{Ma}$ ), while others (Lemoine, 1988 [16], Boher, 1991 [17]) support an establishment during two orogenies, the Burkinian (2400 - $2150 \mathrm{Ma}$ ) and the Eburnean (ss) (2120 - $1800 \mathrm{Ma})$.

The Proterozoic domain of Cote d'Ivoire is marked by a predominance of felsic rocks and an epi to mesozonal metamorphism. It is subdivided according to Papon (1973) [18] into two distinct zones: the SASCA type zone located in the southwest of the country where the Archean formations are well preserved and the zone of geosynclinal type which occupies the rest of the domain. The formations of this second zone are attributed to the Birimian (Arnould, 1961 [19], Bonhomme, 1962 [20]). They are in the form of volcano sedimentary and plutonic belts generally oriented NE-SW and intruded by massive or oriented granitoid (Figure 1).

The auriferous mineralizations of Agbahou, Bonikro, Angovia, Afema, Ton- 
gon, Tengrela, etc., are located in the Proterozoic domain. As for the auriferous mineralization of Ity, it is located in the Toulépleu-Ity belt at the age of Birimian (Feybesse and Milési, 1994 [21], Feybesse et al., 1990 [22]) in the Archean domain (Figure 1).

The geology of the Oume-Fettekro belt, to which the Agbahou deposit belongs, is known from the works of Yace (1982) [23], Lemoine (1988) [16], Mortimer (1990) [24], Leake (1992) [25], Daouda (1998) [26], Houssou (2013) [9], Ouattara Z. (2015) [27], Ouattara Z., et al. (2015) [28], etc. It is formed by a greenstone belt oriented NE-SW to NNE-SSW and delimited by recent granitoid. According to Yace (1982) [23], these birimian formations are formed by schists and quartzites in the midst of which large lenses of volcano-sedimentary rocks appear, some of which may be in synclinal or anticlinal positions.

At the scale of the Agbahou gold deposit, geology is defined by two major lithological units of birimian age intersected by dyke formations: a mafic to intermediate volcanic unit (basalt-andesite) and a volcano-sedimentary unit and associated sediments (Figure 2). This second unit consists of tuff type pyroclastites (mafic and felsic) and metasediments (sandstone, siltstone and shale).

These formations, except the dykes, are generally deformed and metamorphosed in the green schist to amphibolite facies. They occur in the form of metabasalts, meta-andesites, schists (chloritoschists, calcochloritoschists and sericitoschists), amphibolites, mylonites and breccias. The dyke formations are basic to intermediate and acid. The formers appear to be subparallel to schistosity and correspond to microdiorites and microgabbros. The laters, the felsites, formed of rhyolite and rhyodacite intersect the schistosity and show frank contacts with their host rocks, the metabasites.

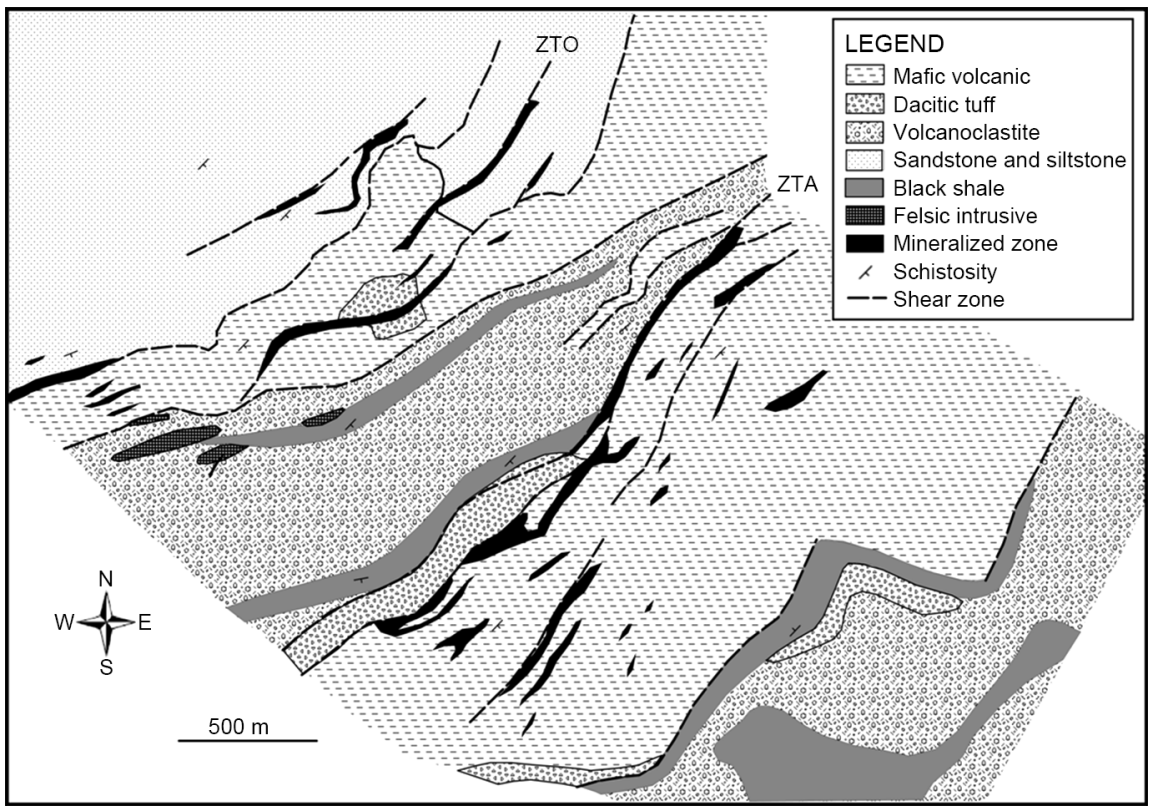

Figure 2. Agbahou Mine Lithostructural Map (Lieben F., et al., 2015, in: Mian, J., 2015 [29]). 


\section{Material and Methods}

Our works are mainly based on the analysis of cores and the interpretation of data. This analysis consists of the cores logging including lithologies and structures description, the measurement of direction and dip or dip-direction of structural features, the selection of samples from different lithologies and mineralizations, the confection of thin sections and their microscopic study.

The description of cores takes into account the intervals of lithological facies and mineralization, their mineralogical composition, the alteration minerals, the sulphides and their proportions, the deformation gradient, the structures, the presence of quartz veins, the weathering profiles and oxidation levels.

Several thin sections (51 in total) of rock and ore samples were made at the University of Accra, Ghana. They were observed with a polarizing microscope in the Laboratory of Geology of the Basement and Metallogeny (LGSM) of Felix Houphouet-Boigny University, Abidjan in Cote d'Ivoire. This microscopic study made it possible to determine the mineralogical assemblages of lithologies, quartz veins and their walls, and to reveal microstructures (schistosities, folds, etc.).

\section{Structural Context of Mineralization}

The Agbahou region experienced significant deformation phenomena, the magnitude of which was revealed by geophysical data (Gillick, 2001) [8], remote sensing (Houssou, 2013) [9], drilling cores (Tourigny, 2008 [30], Tourigny and Houssou, 2008 [31], Houssou, 2013 [9]) and mine pits. These data suggest the existence of a regional tectonic grain parallel to the NE birimian direction and major faults. We distinguish two families of faults: NE faults and NW faults. The NE dislocations correspond to shear zones, the principal of which is called the Agbahou Tectonic Zone (ATZ). It is a first order megastructure, estimated at more than $300 \mathrm{~m}$ wide and $2 \mathrm{~km}$ long (Tourigny, 2008 [30]). A second Tectonic Zone (WTZ) was also highlighted in the Western area. These tectonic zones appear subparallel or intersect at narrow angles the penetrative schistosity S1 oriented NE-SW. The NW dislocations, on the other hand, which appear to be more recent, intersect or simply shift the previous structures.

In fact, the schistosity $\mathrm{S} 1$ is the most common fabric in the volcanic and volcano-sedimentary formations of the Agbahou deposit (Tourigny, 2008 [30]). It affects and obliterates the bedding S0. In metatuffs and metapelites, S0 is the oldest preserved structure. It is expressed by an alternation of centimetric to decimetric levels. The schistosity S1 is penetrative in most formations. S1 is expressed on the one hand by the preferential orientation of phyllite minerals (chlorite, sericite) and carbonates (calcite, dolomite and ankerite) in the hydrothermally altered formations and on the other hand by the flattening of the minerals or clasts in metapyroclastites. S1 is in large part responsible for the tectonic grain of the district and for the spatial distribution of lithologies. At the microscopic scale, schistosity S1 is expressed by an alternation of bands of quartzcalcite and chlorite-epidote \pm biotite \pm sericite in metabasalts and orthoschists or 
sericite-biotite \pm chlorite in metatuffs, metapelites and paraschists (Figure 3(a)). S1 schistosity-parallel calcite veinlets are abundant and show evidence of boudinage and pinch and swell structures.

This S1 schistosity is rarely observed because the drillholes are located at the heart of the shear zone; the shear zone being dominated by a local schistosity or mylonitic schistosity (Sm) more intense as suggested by Bourges et al. (1998) [31]. This schistosity strongly obliterated the regional schistosity S1. S1 and Sm show sometimes similar directions or make small angles between them (Figure 2). They generally follow the Birimian north-east direction with a dip of $50^{\circ}$ to $60^{\circ}$ to the southeast. However, in the flexure zones of the shear zones, they become north-west or north-south and steeply dipping of the order of $70^{\circ}$. Stretching lineations rarely observed in cores indicate the presence of a possible inverse fault movement (Eisenlohr, 1998 [32]).

Deformed rocks often exhibit small-scale crenulation schistosities (Figure 3(a) and Figure 3(b)). This crenulation S2 is characterized by microfolds which intersect and redirect S0 and S1. These microfolds are parallel with vertical to subvertical axial planes, tight to isoclinal (Figure 3(b)). The axes of microfolds seem to orient NS to NNW with wavelengths of around $5 \mathrm{~cm}$ and amplitudes of $3 \mathrm{~cm}$ (Tourigny, 2008 [30]). S2 corresponds to a phase of ductile deformation less intense than that at the origin of the main schistosity.

In the sedimentary rocks, the shear zones are often characterized by transposition phenomena of narrow black shale panels (Figure 3(c)).

At Agbahou, the folds are rather rare; only a few asymmetric folds and intrafoliar folds were observed in drill cores. Their axial planes are generally subparallel to the axial plan of the schistosity S1. Unlikely to folds, the fractures are common. The host rocks appear to be much fractured and form groundwater reservoirs. Under the microscope, micro-fractures are generally filled with

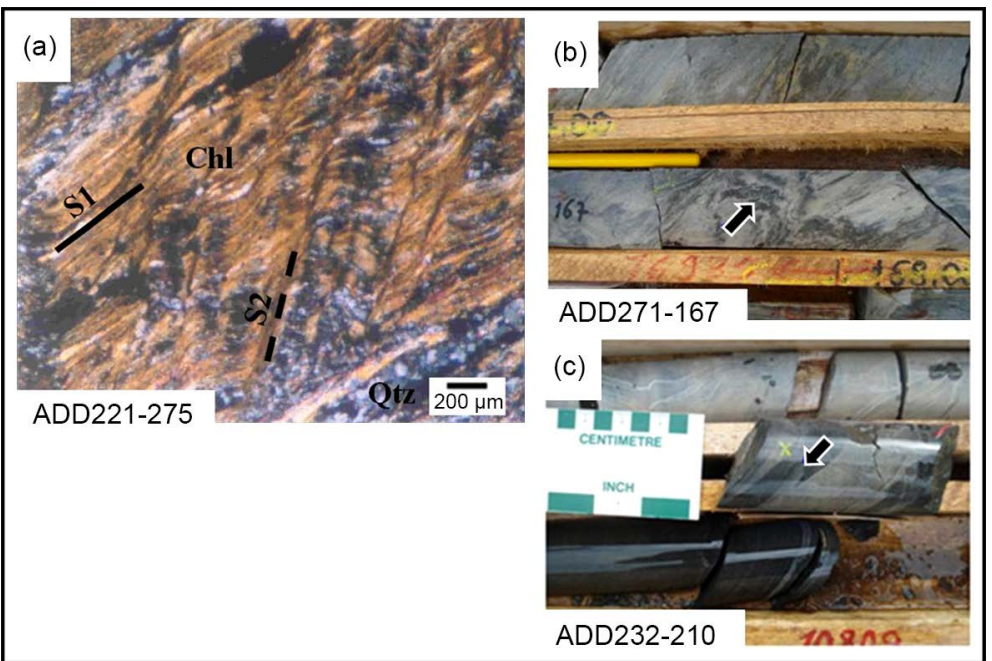

Figure 3. Crenulation schistosities and transposition. (a) Crenulation schistosity S2 undulating the schistosity S1 in a quartz (Qtz) and chlorite (Chl)-rich tectonite. (b) Planar surfaces S0 and S1 crenulated in the hinge of a major fold. (c) Transposition structure (black arrow) with a tectonic band parallel to the schistosity S1. 
quartz, calcite and pyrite minerals. The formation of these fractures was probably due to a post-to-late-tectonic hydraulic fracturing accompanied by a rise in fluids.

\section{Geometrie of Mineralisation of Gold}

\subsection{Shear Zones}

Agbahou gold mineralization appears to be largely controlled by two major Tectonic Zones: ATZ (Agbahou Tectonic Zone) and WTZ (West Tectonic Zone) (Figure 2). The ATZ is developed in the contact zone between a mafic volcanic sequence and a tuff-volcanoclastic sequence (Tourigny and Houssou, 2008 [31]); this contact being oriented NE to NNE and dip $40^{\circ}-60^{\circ} \mathrm{SE}$. The WTZ, on the other hand, appears to be more developed in the mafic volcanic sequence and ends up further north in a sedimentary sequence. It starts in the south by an ENE direction and progressively evolves towards the north in a NNE direction. These main shear zones host several second-order ductile-brittle shear zones. They are posterior to the development of the regional S1 schistosity and carry multiple mineralized quartz veins.

The formations associated with the shear zones are mostly tectonoclasts or tectonic breccias (schists and mylonites) intensely altered (silicification, carbonation and sulphidation and to a lesser degree sericitization and chloritization). The shear schistosity Sm shows a more pronounced development than the regional schistosity S1. This Sm schistosity is generally subparallel to the mineralized lenses and shows an attitude similar to that of the regional schistosity S1. However, in the intensely deformed zones there is a rapid reorientation of the schistosity S1 with a strong angle with respect to the main shear zone.

\subsection{Mineralized Lenses}

The mineralization of Agbahou contains mineralized lenses with multiple quartz veins or heavily sulphurous and gold-bearing zones. In plan (Figure 2), it is observed that the lenses generally follow the shear zones and evolve in NNE to NE or ENE direction (mainly in the west sector). In cross-section, the dips of the mineralized lenses are essentially southeast. In the northern sector, they are $40^{\circ}$ $60^{\circ} \mathrm{SE}$ or $60^{\circ}-70^{\circ} \mathrm{SE}$ dip. In the southern area, mineralization shows more gentle dips of the order of $35^{\circ}-50^{\circ} \mathrm{SE}$. In the western sector, the dips of the mineralized lenses are around $35^{\circ}-45^{\circ} \mathrm{SE}$. According to Tourigny and Houssou (2008) [31], the different lenses are separated from each other by weakly mineralized panels where the ductile deformation appears more important than the hydraulic fracturing. In Agbahou, there are two main types of gold mineralization: the "quartz vein" type and the "pyrite" type associated with calcochloritoschists hosting pyrite and/or calcite veinlets parallel to the schistosity.

\subsection{Veins of Quartz}

Several generations and categories of quartz veins have been highlighted in Agbahou. These veins are generally parallel or intersecting with schistosities. The 
mineralized quartz veins show a NE to NNE direction, but also ENE (sector West) with varying dips: $40^{\circ}-50^{\circ}$ or $70^{\circ}-80^{\circ}$ in the northern sector, $30^{\circ}-40^{\circ}$ in the south and $30^{\circ}-60^{\circ}$ in the western part. However, there are NW or EW directions with steep dips of $70^{\circ}-80^{\circ}$ corresponding in general to measurements probably taken in zones of curvature of sheared veins.

The quartz veins associated with the Agbahou gold mineralization can be classified into three generations:

- The first generation (I) comprises many quartz-carbonate veins and veinlets which are generally parallel to the S1 schistosity. They are found in strongly schistosed panels which are sometimes strongly sulphided, but weakly mineralized in gold. They show microfolds, boudinage and pinch and swell structures.

- The second generation (II) consists of quartz veins which intersect with schistosities and host shear-zones. Gold is associated with quartz-calcite veins with or without tectonoclasts, and sometimes lesser amounts of pyrrhotite, pyrite, arsenopyrite and manganese oxides. The highly mineralized quartz veins are in zones of intense deformation which preferentially develop in the contact zones between the volcanic and sedimentary units.

- The third generation (III) of quartz veins is undeformed and crosscuts all structures and even late acid dykes (rhyolite and rhyodacite). The gold contents of these veins are very low.

However, Agbahou gold mineralization is for the most part controlled by two families of second-generation quartz veins: type IIa veins and type IIb veins. According to Poulsen (1986) [33] and Robert and Brown (1986) [34], the orientation, shape and structural elements of these veins have close geometric relationships with host shear-zones (Figure 4).

\subsubsection{Quartz Veins of Type IIa}

These are smoky quartz veins (Figure 5(a)). They develop in areas of strong brittle deformation. They are veins of lenticular shape which can have thickness
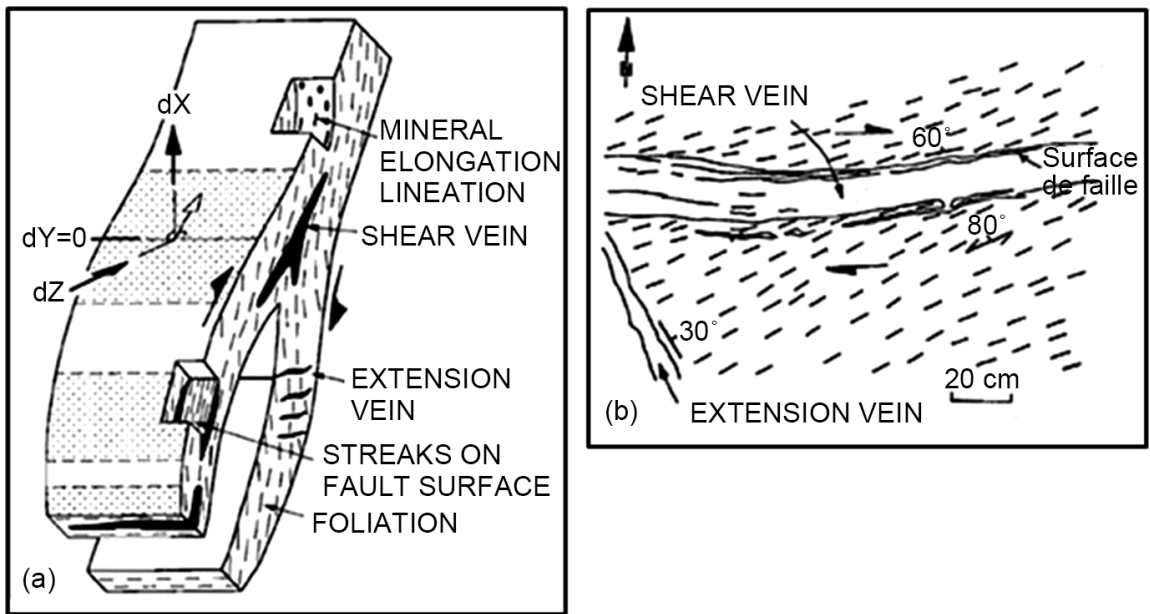

Figure 4. Geometrical relations between shear-zones and quartz veins (Poulsen, 1986 [33]). 
of about ten meters. Geometrically, they are similar to the veins formed parallel to the shear zone (Poulsen, 1986 [33], Robert and Brown, 1986 [34], Figure 4). They have a massive appearance and do not contain fragments of host rocks but are bordered by visible alteration zones (silicification, carbonation, etc.). The veins IIa have a pegmatitic texture and are formed of quartz and plagioclases (Figure 5(b)). The quartz shows microfractures filled with sulphides (pyrite and pyrrhotite) and gold. The plagioclases contain inclusions of quartz, thus showing their posteriority to quartz. Type IIa veins show a low deformation gradient. However, their walls have undergone a higher gradient deformation. They correspond to syntectonic veins which have been placed in fractures associated with the ductile-brittle deformation.

\subsubsection{Quartz Veins of Type IIb}

These are quartz veins mottled by the presence of tectonoclasts from the country rocks. These veins are similar to the extension veins (Poulsen 1986 [33], Robert and Brown 1986 [34], Figure 4). They intersect the schistosity with a high angle and are of variable directions and dips $\left(35^{\circ}-45^{\circ}\right)$.

They are not volumetrically important but are in the form of sigmoidal veins in echelon that can extend over several meters. Type IIb veins are defined by a typical breccia structure containing 30\% - 50\% subangular fragments of hydrothermally altered tectonoclasts (Figure 5(c) and Figure 5(d)). Their implementation was undoubtedly made under conditions of local compression and high differential stresses by one or more fracturing episode (s). These veins are separated by structural panels of low gold content. Type IIb veins are composed of quartz-calcite and tectonoclasts, sometimes containing up to $5 \%$ sulphides (pyrite, pyrrhotite, arsenopyrite and gold). These veins show two mineralogical units under the microscope: a quartz-feldspathic unit with a pegmatitic texture and a tectonoclastic

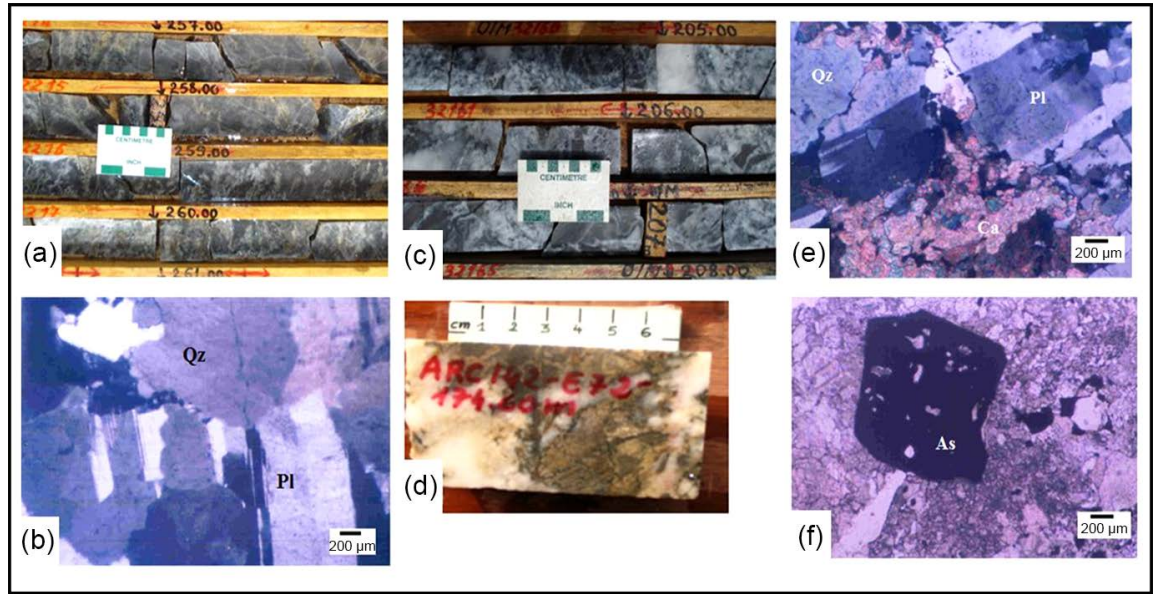

Figure 5. Macroscopic and microscopic appearance of quartz veins. (a) Smoky quartz vein type IIa; (b) Pegmatitic texture with large crystals of fractured quartz and plagioclases; (c) Type IIb quartz vein with subangular and brecciated tectonoclasts; (d) Tectonoclasts in quartz veins of Type IIb; (e) Texture with double lithological unit: a quartzo-plagioclastic unit associated with a tectonoclastic unit rich in chlorite-sericite-carbonates; (f) Phenocrystal subautomorph of arsenopyrite with multiple inclusions of gangue. 
unit with aphanitic texture rich in chlorite, sericite and carbonates (Figure 5(e)). Quartz is generally fractured, while feldspars show signs of distortion. We note the presence of subautomorphic phenocrysts of pyrite or arsenopyrite with multiple inclusions of gangue (Figure 5(f)). Quartz veins type IIb, by their breccia or cataclastic structure show a very strong deformation gradient. Their spatial distribution in gold mineralization suggests that these quartz veins developed between or in shear zones, preferentially in the most carbonated and/or silicified and competent terrains. They recorded several episodes of brittle deformation and did not show significant ductile deformation. They were probably formed under conditions of high local compression by one or more episodes of hydraulic fracturing.

\section{Discussion}

Birimian gold deposits have similar lithostratigraphic contexts, despite some differences noted here and there. The Agbahou gold deposit is regionaly located in the Oume-Fettekro greenstone belt intruded by granitoids. Locally, the deposit contains a mafic to intermediate volcanic unit (basalt and andesite), a volcanosedimentary unit (tuff and volcanoclastite) and a sedimentary unit (sandstone, siltstone and shale), all stretched in the NE-SW birimian direction. They are intruded by concordant dykes of diorite and gabbro, and by discordant dykes of rhyodacite and rhyolite. Generally, the mineralization of Agbahou appears to develop more in mafic volcanics than in volcanoclastites and sediments. Agbahou's litho-structural data are similar to the regionally known gold deposits. One can cite the gold mineralizations of the Afema province (south-east of Cote d'Ivoire) which are located in the contact zone between volcanic and volcano-sedimentary birimian formations oriented NE and intruded by plutonites.

Our work suggests that the Agbahou deposit is controlled by two major shear zones: ATZ (Agbahou Tectonic Zone) and WTZ (West Tectonic Zone). These shear zones can be interpreted as first order megastructures (Robert and Brown, 1986 [34]; Robert, 1990 [35]). Similar to several gold mineralizations in Côte d'Ivoire (Aféma, Angovia, etc.) and elsewhere in West Africa, these NE-SW to NNE-SSW oriented shear zones occupy the contact zones or are squarely developed in a single sequence of rocks. The Ashanti gold deposits (Ashanti, Konongo, Bogosu, Prestea and Abawso mines) (Oberthür et al., 1997 [36], Wille and Klemd, 2004 [37]) and also the gold deposits of Bonikro (Ouattara, 2015 [27]) and Bobosso (Gnanzou, 2014 [38]), for example, are located in NE-NNE shear zones and intersect birimian sediments near volcanic contact.

The ATZ and the WTZ probably correspond to major fault systems developed on the eastern and western limb, not far from the hinges of an Anticlinorium (Figure 2); this anticlinal plunging moderately towards the northeast (Sinclair, 1999 [39]). According to Tourigny (2008) [30], the dip would be of the order of $25^{\circ}$. Significant gold concentrations of Agbahou (>1.0 g/t Au) plunge $25^{\circ}$ towards the northeast (Tourigny and Houssou, 2008 [31]). This plunge of gold mineralization probably suggests the existence of deep unexplored lenses or 
quartz veins.

Like Agbahou, the Abawso gold deposit is located on the north-west limb steeply dipping of an anticline, with an axis plunging rather towards south-west (Wille and Klemd, 2004 [37]). The NE plunge of the Agbahou gold mineralization could reveal the existence of unexplored quartz veins and/or indicate the origin and the circuit of the mineralizing fluids (Tourigny and Houssou, 2008 [31]). Following the example of several world-known gold mineralizations, Agbahou is regionally located not far from granitoid intrusion. The host formations of the auriferous mineralization are deformed, metamorphosed and marked by a higher schistosity and an important mylonitisation. ATZ and WTZ show contours parallel to the regional schistosity that would result from both the NW-SE regional shortening and diapirism-forming granitoids during the Eburnian tectonothermal event between 2.2 and 2.1 Ga (Feybesse et al., 2006 [3], Lompo, 2009 [40]). Within the Agbahou deposit, two families of major faults are distinguished: NE faults and NW faults. According to Milési et al. (1992) [13], Vidal and Alric (1994) [41], Feybesse et al. (2006) [3] and Lompo (2009) [40], the NW faults correspond to strike slip faults and their development in the West African Birimian is attributed to transcurrent tectonics. However, here they seem not to be marked by a major displacement. On the other hand, they acted as channels controlling the distribution of gold mineralization (Feybesse et al., 2006 [3]). They transported and trapped hydrothermal fluids. The shear zones of Agbahou, Sabodala in Senegal (Sylla and N'gom, 1997 [42]), Abawso in Ghana (Wille and Klemd 2004 [37]) and Taparko in Burkina Faso (Bourges et al., 1998 [43]) show the same sinistral reverse displacement, the orientations being variable and respectively N020-N040, NS-N020, N100-120 and N170. According to Bourges et al. (1998) [43], transcurrent sinistral shear has evolved towards inverse sinistral shear. As for the Diabatou gold shear zone (in Burkina Faso), it is marked by an inverse dextral movement (Milési, 1989 [44], Milési et al., 1992 [13], Klemd et al., 1997 [45]). The Harbor Lights gold deposit in Australia, on the other hand, is interpreted as a normal shear zone with a dip around $30^{\circ}$ (Skwarnecki, 1987 [46] and 1988 [47]; Vearncombe, 1992 [48]) in which the deformation processes are partly similar to those of inverse shear zones containing most of the gold deposits.

The main ATZ shear zone contains more than eight (8) supposed secondorder ductile-fragile shear-zones (Robert and Brown, 1986 [34]; Robert, 1990 [35]) of NE-SW direction and dip $50^{\circ}-80^{\circ}$ SE. These shear zones of smaller scales are posterior to the development of the schistosity S1 and contain the main auriferous quartz veins. Work by Wille and Klemd (2004) [37] on the Abawso gold deposit (Ghana) revealed features similar to Agbahou with a NNE orientation and a dip of $50^{\circ}-90^{\circ}$ SE. Similar mineralized lenses of NE-SW to NNE-SSW orientation and steeply dipping, which are parallel to the regional schistosity, are also observed in the Ashanti belt deposits (in Ghana).

In Agbahou and in most auriferous deposits, there is a polyphase deformation with fracturing which has manifested in several ways. This fracturing is respon- 
sible for the formation of several generations of quartz veins. According to Bonnemaison (1986) [49], Herrington and Wilkinson (1993) [50], the deformation evolved from a ductile to a ductile-brittle style following the classical evolution of gold-bearing quartz veins. The NE and NNE stretching of the main shear zones shows that the Agbahou gold deposit is closely related to the Eburnean event $(2120$ - $1800 \mathrm{Ma})$. This explains its similarity with several known gold deposits in the West African and, in particular, Côte d'Ivoire birrimian lands.

\section{General Conclusions}

Remote sensing, geophysics and drilling have established the litho-structural context of the Agbahou gold deposit. This work reveals that this region is characterized by a large stable zone formed of granitoid, intruding an unstable domain with particularly high topographies. This area, composed of volcanic, volcano sedimentary and sedimentary sequences of birimian age, is home to numerous faults, some of which are responsible for the emplacement of Agbahou gold mineralization.

Agbahou gold mineralization is controlled by two major shear zones: ATZ (Agbahou Tectonic Zone) and WTZ (West Tectonic Zone). They are generally oriented NE to NNE and located in birimian volcanic, volcano sedimentary and sedimentary assemblages intruded by granitoids. Drill core studies reveal intensively deformed ductile-brittle deformation in contact zones (N040, 50 ${ }^{\circ} \mathrm{SE}$ ) between soft sediments and more competent volcanics. It controls the emplacement of mineralized lenses and gold-bearing quartz veins. The contours of the shear zones (ATZ and WTZ) are parallel to the regional schistosity. The firstorder shear zones have second-order ductile-brittle shear zones, oriented NE to $\mathrm{NNE}$ and dipping $50^{\circ}-80^{\circ} \mathrm{SE}$. These secondary shear zones host multiple goldbearing quartz veins.

The structure of Agbahou deposit consists of two major events: 1) regional plicative deformation at the origin of NE-NNE stretching of regional tectonic fabrics, accompanied by a green schist facies metamorphism; 2) faults formation, reactivation of regional tectonic fabrics, development of Tectonic Zones (ATZ and WTZ) and formation of secondary structures, accompanied by metamorphism, sometimes reaching amphibolite facies. This implementation of the faults induced hydraulic fracturing in areas of high pressure and favored the formation of gold-bearing hydrothermal quartz veins.

Our work lists the potential targets as a priority for future follow-up work in the area. It includes geological and metallogenic data which can serve as a guideline for mining prospecting. It is a good contribution to the study of deposits of gold mineralization in West Africa.

\section{References}

[1] Hein, K.A.A., Morel, V., Kagone, O., Kiemde, F. and Mayes, K. (2004). Birimian Lithological Succession and Structural Evolution in the Goren Segment of the Boromo-Goren Greenstone Belt, Burkina Faso. Journal of African Earth Sciences, 39, 1 23. https://doi.org/10.1016/j.jafrearsci.2004.05.003 
[2] Hein, K.A.A. (2010). Succession of Structural Events in the Goren Greenstone Belt (Burkina Faso): Implications for West African Tectonics. Journal of African Earth Sciences, 56, 83-94. https://doi.org/10.1016/j.jafrearsci.2009.06.002

[3] Feybesse, J.L., Billa, M., Guerrot, C., Duguey, E., Lescuyer, J.L., Milesi, J.P. and Bouchot, V. (2006). The Paleoproterozoïc Ghanaian Province: Geodynamic Model and Ore Controls, Including Regional Stress Modeling. Precambrian Research, 149, 149-196. https://doi.org/10.1016/j.precamres.2006.06.003

[4] Tshibubudze, A., Hein, K.A.A. and Marquis, P. (2009). The Markoye Shear Zone in NE Burkina Faso. Journal of African Earth Sciences, 55, 245-256. https://doi.org/10.1016/j.jafrearsci.2009.04.009

[5] Lompo, M. (2010). Structural Evolution of Paleoproterozoïc Belts (Eburnean Event) in the Man-Leo Shield, West African Craton. Key Structures for Vertical to Transcurrent Tectonics. Journal of African Earth Sciences, 58, 19-36. https://doi.org/10.1016/j.jafrearsci.2010.01.005

[6] Baratoux, L., Metelka, V., Naba, S., Jessell, M.W., Gregoire, M. and Ganne, J. (2011) Juvenile Paleoproterozoic Crust Evolution during the Eburnean Orogeny ( 2.2 - 2.0 Ga), Western Burkina Faso. Precambrian Research, 191, 18-45. https://doi.org/10.1016/j.precamres.2011.08.010

[7] Perrouty, S., Aillères, L., Jessell, M.W., Baratoux, L., Bourassa, Y. and Crawford, B. (2012) Revised Eburnean Geodynamic Evolution of the Gold-Rich Southern Ashanti Belt, Ghana, with New Field and Geophysical Evidence of Pre-Tarkwaian Deformations. Precambrian Research, 204, 12-39. https://doi.org/10.1016/j.precamres.2012.01.003

[8] Gillick, B. (2001) Comments on Airborne Geophysics of Agbahou and Hiré Permits (Côte d'Ivoire). Memorandum of Robert E. Gillick \& Associates Ltd., Geophysical Consulting \& Contracting, $14 \mathrm{p}$.

[9] Houssou, N.N. (2013) Petrological, Structural, Geochem and Metallogenic Study of the Agbahou Gold Deposit, Divo, Côte d'Ivoire. Thesis Unique, Univ. Felix Houphouet Boigny-UFR STRM, Memory, 257 p.

[10] Tshibubudze, A. and Hein, K.A.A. (2013) Structural Setting of Gold Deposits in the Oudalan-Gorouol Volcano-Sedimentary Belt East of the Markoye Shear Zone, West African Craton. Journal of African Earth Sciences, 80, 31-47. https://doi.org/10.1016/j.jafrearsci.2012.11.010

[11] Bessoles, B. (1977) Geology of Africa. The West African Craton. Memory in BRGM, No. 88, 402 p.

[12] Pothin, K.B.K., Gioan, P. and Gronayes, C.C. (2000) Geochronological Assessment of the Precambrian Basement of Côte d'Ivoire. Bioterre, International Journal of Sciences, 1, 36-47.

[13] Milesi, J.P., Ledru, P., Feybesse, J.L., Dommanget, A. and Marcoux, E. (1992) Early Proterozoïc Ore Deposits and Tectonics of the Birimian Orogenic Belt, West Africa. Precambrian Research, 58, 305-344. https://doi.org/10.1016/0301-9268(92)90123-6

[14] Tagini, B. (1971) Structural Sketch of the Ivory Coast: Regional Geotectonics Trial. Doctorate, Univ. Lausanne, Côte d'Ivoire (SODEMI), Bull. No. 5, 302 p.

[15] Yace, I. (1993) Precambrian Volcano-Sedimentary Complexes in West Africa. Lower Proterozoic Symposium, CIFEG, 23.

[16] Lemoine, S. (1988) Geological Evolution of the Dabakala Region (NE of the Ivory Coast) to the Lower Proterozoic. Doctorate of Science, Univ. Clermont, Ferrand, $388 \mathrm{p}$.

[17] Boher, M. (1991) Crustal Growth in West Africa at 2.1 Ga. Contribution of Isotopic 
Geochemistry. Doctorate, Univ. Nancy, Nancy, 180 p.

[18] Papon, A. (1973) Geology and Mineralization of Southwestern Côte d'Ivoire. Memory of the BRGM, Paris, No. 80, 284 p.

[19] Arnould, A. (1961) Geological Study of Precambrian Migmatites and Granites in Northeastern Côte d'Ivoire and Southern Haute-Volta. Memory in BRGM, No. 3, $175 \mathrm{p}$.

[20] Bonhomme, M. (1962) Contribution to the Geochronological Study of the West African Platform. Doctorate, Ann. Fac. Sc. Univ., Clermont, Ferrand, No. 5, 62 p.

[21] Feybesse, J.L. and Milesi, J.P. (1994) The Archaean/Proterozoic Contact Zone in West Africa: A Mountain Belt of Décollement Thrusting and Folding on a Continental Margin Related to 2,1 Ga Convergence of Archaean Cratons? Precambrian Research, 69, 199-227. https://doi.org/10.1016/0301-9268(94)90087-6

[22] Feybesse, J.L., Milesi, J.P., Ouedraogo, M.F. and Prost, A. (1990) The Lower Proterozoic belt of Boromo-Goren, Burkina Faso: An Example of Interference between Two Transcurrent Eburnian Phases. Accounts of the Academy of Sciences, Paris, No. 310, 1353-1360.

[23] Yace, I. (1982) Geological Study of Eburnéan Volcanism in the Central and Southern Parts of the Precambrian Chain of Fettêkro. Ministry of Mines. Republic of Côte d'Ivoire, $156 \mathrm{p}$.

[24] Mortimer, J. (1990) Evolution of Early Proterozoïc Toumodi Volcanic Group and Associated Rocks, Ivory Coast. PhD Thesis, Portsmouth Polytechnic, Portsmouth, $244 \mathrm{p}$.

[25] Leake, M.H. (1992) The Petrogenesis and Structural Evolution of the Early Proterozoïc Fettêkro Greenstone Belt, Dabakala Region, NE Côte d'Ivoire. PhD. Thesis, University of Portsmouth, Accounts of the Academy of Sciences, 315 p.

[26] Daouda, Y.B. (1998) Lithostratigraphy and Petrology of the Birimian Formations of Toumodi-Fettêkro, Côte d'Ivoire: Implication for the Crustal Evolution of the Palaeo-Proterozoic of the West African Craton. Doctorate, Univ. Orleans, Orleans, Memory 737, $191 \mathrm{p}$.

[27] Ouattara, Z. (2015) Lithostratigraphic, Structural, Geochem and Metallogenic Characters of Bonikro Gold Deposit, Fettekro Birimian Belt, Centre-South of Côte d'Ivoire. Thesis Unique, Univ. Felix Houphouet Boigny, Felix Houphouet Boigny, $330 \mathrm{p}$.

[28] Ouattara, Z., Coulibaly, Y. and Lieben, F. (2015) Petrography of Bonikro Gold Deposit, Oume-Fettekro Greenstone Belt. Côte d'Ivoire. European Scientific Journal, 11, 119-132.

[29] Lieben, F., Kangah, J. and Ouattara, G. (2015) Activities Report on Agbahou Gold Mine (2012-2015). In: Mian, J., Ed., Core Drilling Study: Highlighting of the Knowledge of Lithostructural Context of Agbahou Gold Deposit, Univ. Joseph Fourier, Grenoble, 65.

[30] Tourigny, G. (2008) Core-Scale Observations of the Agbahou Gold Deposit: Preliminary Overview and Interpretation. Unpublished Memorandum, Etruscan Resources Inc., $16 \mathrm{p}$.

[31] Tourigny, G. and Houssou, N.N. (2008) Additional Comments on the Agbahou Gold Deposit. Unpublished Memorandum, Etruscan Resources Inc., 12p. (With 29 $\mathrm{p}$ of Figures)

[32] Eisenlohr, B.N. (1998) Agbahou Gold Project: Geology and Mineralization. Report Prepared for Jandera Resources NL, 3-D Geological Services Pty Ltd., 58 p.

[33] Poulsen, K.H. (1986) Auriferous Shear Zones with Examples from the Western 
Shield. In: Clark L.L., Ed., Gold in the Western Shield, Canadian Institute of Mining and Metallurgy, Special 38, 86-103.

[34] Robert, F. and Brown, A.C. (1986) Archean Gold-Bearing Quartz Veins at the Sigma Mine, Abitibi Greenstone Belt, Quebec. Part I. Geologic Relations and Formation of the Vein System. Economic Geology, 81, 578-592.

https://doi.org/10.2113/gsecongeo.81.3.578

[35] Robert, F. (1990) Structural Setting and Control of Gold-Quartz Veins the Val d'Or Area, South-Eastern Abitibi Sub-Province, in Gold and Base-Metal Mineralization in the Abitibi Sub-Province, Canada, with Emphasis of the Quebec Segment. Geology Department (Key Centre) and University Extension, the University of Western Australia. Publication No. 24, 167-210.

[36] Oberthür, T., Weiser, T. and Amanor, J.A. (1997) Mineralogical Sitting and Distribution of Gold in Quartz Veins and Sulphide Ores of the Ashanti Mine and Other Deposits in the Ashanti Belt of Ghana: Genetic Implications. Mineralium Deposita, 32, 2-15. https://doi.org/10.1007/s001260050068

[37] Wille, S.E. and Klemd, R. (2004) Fluid Inclusion Studies of the Abawso Gold Prospect, Near the Ashanti Belt, Ghana. Mineralium Deposita, 39, 31-45. https://doi.org/10.1007/s00126-003-0380-1

[38] Gnanzou, A. (2014) Study of Volcanosedimentary Series of Dabakala Region (North-East of Côte d'Ivoire): Genesis and Magmatic Evolution. Contribution to the Knowledge of Bobosso Gold Mineralization Located in the Haute-Comoe Serie. Thesis Unique, Univ. Paris-Sud XI, Faculté des Sciences d'Orsay, 258 p.

[39] Sinclair, C. (1999) Quarterly Report of Agbahou PR Project No. 100. Goldivoire SARL, $18 \mathrm{p}$.

[40] Lompo, M. (2009) Geodynamic Evolution of the 2.25-2.0 Ga Paleoproterozoïc Magmatic Rocks in the Man-Leo Shield of the West African Craton. A Model of Subsidence of an Oceanic Plateau. In: Geological Society of London, Eds., Paleoproterozoïc Supercontinents and Global Evolution, SP 323, 231-254.

[41] Vidal, M. and Alric, G. (1994) The Paleoproterozoïc (Birimian) of Haute-Comoé in the West African Craton, Ivory Coast: A Transtensional Back-Arc Basin. Precambrian Research, 65, 207-229. https://doi.org/10.1016/0301-9268(94)90106-6

[42] Sylla, M.. and Ngom, P.M. (1997) The Gold Deposit of Sabodala (Eastern Senegal): A Vein Mineralization of Hydrothermal Origin Remobilized by a Shearing Tectonics. Journal of African Earth Sciences, 25, 183-192. https://doi.org/10.1016/S0899-5362(97)00097-3

[43] Bourges, F., Debat, P., Tollon, F., Munoz, M. and Ingles, J. (1998) The Geology of the Taparko Gold Deposit, Birimian Greenstone Belt, Burkina Faso, West Africa. Mineralium Deposita, 33, 591-605. https://doi.org/10.1007/s001260050175

[44] Milesi, J.P. (1989) West Africa Gold Deposits in Their Lower Proterozoïc Lithostructural Setting. Chronique Recherche Minière, 497, 3-98.

[45] Klemd, R., Oberthür, T. and Ouedraogo, A. (1997) Gold Telluride Mineralization in the Birimian at Diabatou, Burkina Faso: The Role of $\mathrm{CO}_{2}-\mathrm{N}_{2}$ Fluids. Journal of African Earth Sciences, 24, 227-239. https://doi.org/10.1016/S0899-5362(97)00040-7

[46] Skwarnecki, M.S. (1987) Controls on Archean Gold Mineralization in the Leonora District, Western Australia. In: Ho, S.E. and Groves, D.I., Eds., Recent Advances in Understanding Precambrian Gold Deposits, Geol. Dept. and Univ. Ext., Univ. West. Aust. 11, 109-136.

[47] Skwarnecki, M.S. (1988) Alteration and Deformation in a Shear Zone Hosting Gold Mineralization at Harbour Lights, Leonora, Western Australia. In: Ho, S.E. and 
Groves, D.I., Eds., Recent Advances in Understanding Precambrian Gold Deposits, Geol. Dept. and Univ. Ext., Univ. West. Aust. 12, 111-129.

[48] Vearncombe, J.R. (1992) Archean Gold Mineralization in a Normal-Motion Shear Zone at Harbour Lights, Leonora, Western Australia. Mineralium Deposita, 27, 182-191. https://doi.org/10.1007/BF00202541

[49] Bonnemaison, M. (1986) Gold-Bearing Quartz Veins: A Special Case of Gold ShearZone. Chronic of Mining Research, 482, 55-56.

[50] Herrington, R.J. and Wilkinson, J.J. (1993) Colloidal Gold and Silica in Mesothermal Veins Systems. Geology, 21, 534-542.

https://doi.org/10.1130/0091-7613(1993)021<0539:CGASIM>2.3.CO;2

Submit or recommend next manuscript to SCIRP and we will provide best service for you:

Accepting pre-submission inquiries through Email, Facebook, LinkedIn, Twitter, etc. A wide selection of journals (inclusive of 9 subjects, more than 200 journals)

Providing 24-hour high-quality service

User-friendly online submission system

Fair and swift peer-review system

Efficient typesetting and proofreading procedure

Display of the result of downloads and visits, as well as the number of cited articles

Maximum dissemination of your research work

Submit your manuscript at: http://papersubmission.scirp.org/

Or contact ijg@scirp.org 